\title{
THE RESPONSE TIME OF GLACIERS IN ICELAND TO CHANGES IN CLIMATE
}

\author{
by \\ Tómas Jóhannesson
}

(Science Institute, University of Iceland, Dunhagi 3, 107 Reykjavík, Iceland)

\begin{abstract}
Records of the time variation of the terminus position of Icelandic glaciers since 1700 show clear responses to the little ice age and to the warm period from 1930 to 1960 . These data are used to deduce limits for the response time of the glaciers. The response time turns out to be of the order of one or two hundred years. This is much shorter than the "long response time" of Nye's kinematic wave theory.
\end{abstract}

\section{INTRODUCTION}

The response time of a glacier indicates how long it takes the glacier to adjust to a change in its mass balance The response time of glaciers is of fundamental importance for the understanding of the response of glaciers to climatic changes. It is also of importance when glacier oscillations are interpreted in terms of climatic history.

According to Nye's (1963) kinematic wave theory, diffusion of kinematic waves leads to a very long response time of glaciers, between one and two orders of magnitude longer than would be expected if diffusion is not taken into account (Paterson, 1981, pp. 256-258). This "long response time" is of the order of 1000 years for the outlet glaciers of the Icelandic ice caps.

The oscillations of the Icelandic glaciers, since about 1700, have been estimated on the basis of old maps, historical evidence, and other available material. Since 1930, direct measurements of the changing position of many termini are available. The purpose of this paper is to use the available information on the reponse of the Icelandic glaciers to known climatic changes, to deduce limits to the response time of the glaciers and to see whether these limits are consistent with the "long response time" of Nye's kinematic wave theory.

ESTIMATION OF RESPONSE TIME FROM DATA ON THE ADVANCE AND RETREAT OF THE TERMINUS

If the climatic history contains changes of different time scales, the response time of a glacier can be estimated by finding the time scale for which the transition between two types of response occurs:

i) When the time scale of a climatic change is considerably shorter than the response time, the glacier does not have time to reach equilibrium with respect to the varying climate. The glacier will therefore advance (retreat) during periods of positive (negative) mass-balance perturbation, with the maximum rate of advance (retreat) occurring when the mass-balance perturbation is at its maximum (minimum).

ii) When the time scale of the climatic change is considerably longer than the response time, the glacier will be close to equilibrium at all times. The extension of the glacier will thus be at its maximum (minimum) shortly after the mass-balance perturbation is at its maximum (minimum). The time lag between the mass-balance perturbation and the extension of the glacier is equal to the reponse time. In this case, the glacier will start retreating shortly after the mass-balance perturbation is at its maximum, when the perturbation is still positive.

\section{THE CLIMATIC HISTORY}

The extension of the glaciers in Iceland since 1700 is affected by two, distinct, climatic changes of very different time scales: the little ice age and the climatic optimum from 1930 to 1960 .

Temperature measurements and estimates will be used to indicate the mass-balance history of the glaciers, since direct measurements of the mass balance are not available. The main effect of a temperature change is to change the ablation rate. Therefore, the summer temperature is, when available, preferable to the yearly mean temperature as an indication of the mass balance. It is shown, in a study by Eythórsson and Sigtryggsson (1971), that the temperature history of 6 weather stations, in different parts of Iceland, from 1900 to 1950 , is fairly similar. For example, the increase in the temperature around 1930 occurs at the same time and is of similar magnitude at all the stations. Thus, the temperature record of a convenient weather station represents the long term temperature changes on the glaciers.

Figure 1, bottom, shows the summer temperature and its decadal running average at Stykkishólmur, in western Iceland, from 1846 (data provided by Iceland Meteorological Office). It shows an approximately 30-year long, warm period, between 1930 and 1960 .

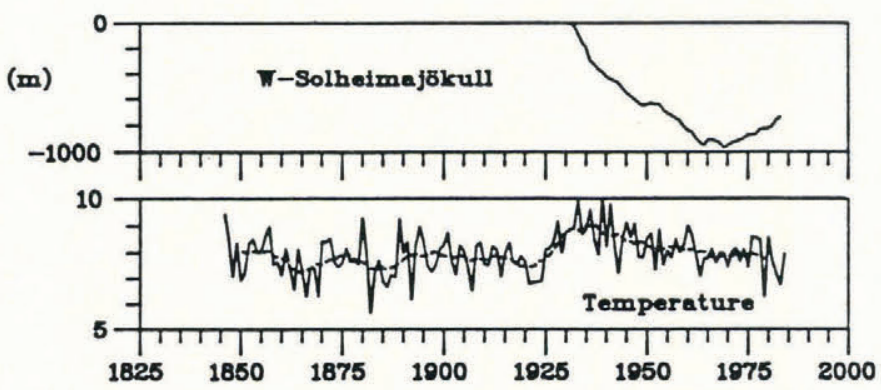

Fig.1. Top: W-Sólheimajökull, net recession since 1930. From Björnsson (1979). Bottom: Mean summer temperature (May - September) in Stykkishólmur.

The temperature history before 1846 must be estimated from indirect evidence. Figure 2, bottom, shows a temperature estimate for Iceland for the past 1000 years (Bergthórsson, 1969). It is based on historical information about sea ice and severe years. The gap in the curve in the fifteenth century is because of lack of data. The figure shows an approximately 700-year long cool, period, starting around 1200, with the coldest temperatures occurring between 1600 and 1900 .

The estimate of the temperature history before 1846 must be considered to be very uncertain. Bergthórsson's estimate does not agree well with the Northern Hemisphere temperature index (Hammer and others, 1980), which is based on temperature estimates from England, USA, and Greenland. Whether this is caused by local climatic changes in Iceland, or errors in Bergthórsson's estimate, or the $\mathrm{NH}$ temperature index, or both, is not clear. Ogilvie (1984) has 
constructed sea-ice and temperature indices for Iceland, for the time period 1600 to 1780 . Her temperature index is based on historical evidence and is independent of her sea-ice index. It shows broad agreement with Bergthórsson's results for this period, which is the most critical period for the conclusions of this paper.

\section{THE RESPONSE OF THE GLACIERS}

\section{The climatic optimum between 1930 and 1960}

The response of the glaciers in Iceland to the warm period between 1930 and 1960 is well documented (Rist, 1967 - 1984). All non-surging glaciers, which where monitored, retreated during the whole period, except that the outlet glaciers of the ice cap, Drangajökull, advanced for a few years around 1935. The cause of this advance is not known, but it may have been caused by a local climatic change.

Figure 1, top, shows the position of the terminus of W-Sólheimajökull, since 1930 (Björnsson, 1979). The response shown in the figure is very similar to the response of over 10 outlet glaciers from the ice cap, Vatnajökull, and the ice cap, Mýrdalsjökull (Björnsson, personal communication). It can therefore be taken as a typical response of the outlet glaciers of these ice caps.

Figure 1 shows that the rate of retreat slows down from a maximum, shortly after 1930, to zero, shortly after 1960 , and that the summer temperature varies in a very similar way. This relation between the summer temperature and the rate of retreat corresponds to case i) in section 2 . It may, therefore, be concluded that the response time of the Icelandic glaciers is considerably longer that the time scale of the climatic optimum, say 30 years.

\section{The little ice age}

Figure 2. middle and top, shows an approximate average of the oscillations of the outlet glaciers of the ice cap, Drangajökull, and the south-flowing, outlet glaciers of the ice cap, Vatnajökull, since 1700 (Thórarinsson, 1943).

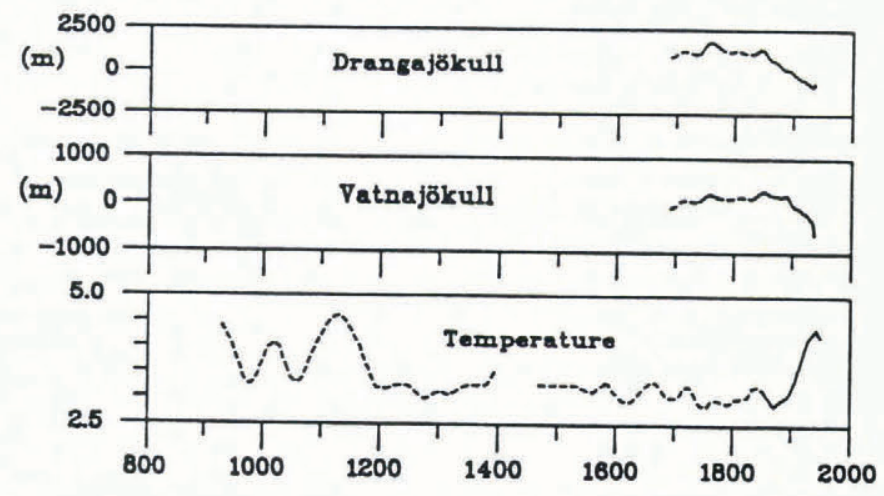

Fig.2. Top and middle: Oscillations of the Drangajökull outlet glaciers and the $\mathrm{S}$ outlet glaciers of Vatnajökull. From Thórarinsson (1943). Bottom: Running 30 year mean of the temperature in Iceland. From Bergthórsson (1969). small, compared to the advance before 1750 , or the retreat after 1890. This indicates that the glaciers had more or less adjusted to the cold temperatures of the little ice age by 1750. This corresponds to case ii) of section 2 and shows that the response time is considerably shorter than the time scale of the little ice age, say 700 years.

\section{CONCLUSION}

The response time of the Icelandic glaciers is considerably longer than 30 years and considerably shorter than 700 years. This leads to a response time of the order of one or two hundred years. This is not to say that all glaciers in Iceland have the same response to climatic changes. The above limits and order of magnitude estimate allow for a wide variety of responses of individual glaciers, depending, for example, on size and local climatic conditions.

The above, order-of-magnitude estimate is not consistent with the "long response ltime" (of the order of 1000 years) of Nye's kinematic wave theory.

\section{REFERENCES}

Bergthórsson P 1969 An estimate of drift ice and temperature in Iceland in 1000 years. Jökull 19: 94-101

Björnsson H 19799 glaciers in Iceland. Jökull 29: 74-80

Eythórsson J, Sigtryggsson H 1971 The climate and weather of Iceland. Zoology of Iceland 1(3)

Hammer C U, Clausen H B, Dansgaard W 1980 Greenland ice sheet evidence of post-glacial volcanism and its climatic impact. Nature 288(5788): 230-235

Nye J F 1963 On the theory of the advance and retreat of glaciers. Geophysical Journal of the Royal Astronomical Society 7(4): 431-456

Ogilvie A E J 1984 The past climate and sea-ice record from Iceland. Part 1: data to a.d. 1780. Climatic Change 6: $131-152$

Paterson W S B 1981 The physics of glaciers. Second edition. Oxford etc, Pergamon Press

Rist S 1967-1984 Jöklabreytingar/Glacier variations in metres. Jökull 17-34

Thórarinsson S 1943 Vatnajökull. Scientific results of the Swedish-Icelandic investigations 1936-37-38. Oscillations of the Iceland glaciers in the last 250 years. Geografiska Annaler 25(1-2): 1-54
There are some gaps in the data and the responses of the outlet glaciers are not all the same, although they are fairly similar. Nevertheless, the general picture is relatively certain. The glaciers advance before 1750 . In the period 1750 to 1850 , the extension of the glaciers reaches a relatively flat maximum. The outlet glaciers of Drangajökull, which is a much smaller ice cap than Vatnajökull, start retreating about 1850 , but the retreat of the outlet glaciers of Vatnajökull does not set in until about 1890 .

The response of the glaciers to the little ice age is strikingly different from their response to the climatic optimum between 1930 and 1960. Bergthorsson estimates that the period between 1750 and 1800 was perhaps the coldest period of the little ice age in Iceland. If this is true, then the period of the coldest temperatures occurred when the extension of the glaciers was changing very slowly. Moreover, the period from 1700 to 1900 was quite cold, whereas the advance of the glaciers slowed down around 1750 and the oscillations of Vatnajökull until 1890 were 